\title{
The Good Citizen: problematising citizenship in the social sciences curriculum
}

\begin{abstract}
This article explores the critical pedagogical issues which emerge when attempting to develop active citizenship among undergraduates as an integral part of the student experience. It presents part of the findings from a C-SAP-funded project (Gifford et al. 2006) which we undertook with a partner HEI. This paper explores our particular contribution carried out in a post-1992 London HEI. Our innovations in the Social Sciences undergraduate curriculum aimed at creating situations in which students would explore the diversity of citizenship in educational settings, namely, a local school, a further education college, and Summerhill School (founded by A.S. Neill). The research leads us to conclude that citizenship is a problem of praxis influenced and shaped by the localglobal contexts of communities with diverse heritages of meaning, stratified social settings, and specific local and historical characteristics. This challenges the notions underpinning the Crick curriculum with its national orientation, and demonstrates the need to sensitise citizenship learning experiences to the needs of students and staff embedded in their social contexts. Such an approach can be understood as a form of situated citizenship characterised by active engagement with an assumption of heterogeneity which is positively sensitive to diversity.
\end{abstract}

Keywords: active citizenship, situated citizenship, Summerhill, student led, social sciences, governance

\section{Introduction}

This article explores the methods and outcomes of a C-SAP-funded project (Gifford et al. (2006) which we undertook with a partner higher education institution. The aim of the project, Working with Schools: Active Citizenship for Undergraduate Students, was to explore innovations in the learning and teaching of citizenship in the undergraduate curriculum in the Social Sciences through involving students in building democratic capacity in schools. In this article, we examine our specific contribution to the project at our post 1992 University, which raised issues about the diversity of concepts and formations of citizenship in education. We also consider that pedagogical needs require responses which are sensitised and particular to people living in their local contexts.

Our project took the form of an innovative second level undergraduate module Doing Citizenship, offered as an option on the BA Sociology programme which we concurrently researched and delivered. The aim of the module was to explore concepts and formations of citizenship in education in theory and practice, allowing students to reflect upon their own assumptions about citizenship. We started by considering the educational biographies of our students and found they included fee paying schools, local authority provision, and a range of post compulsory provision at different stages in the lifecourse. As a result, we decided to select educational settings for the project which went beyond local schools to include a post compulsory setting and an alternative model from an independent school. This selection reflected the diversity of compulsory and post compulsory routes into Higher Education taken by our students. It also allowed students to explore both the formal and informal curriculum of citizenship as presented in the different settings, with strong contrasts between for example, taught citizenship classes in a secondary school and the expression of citizenship at Summerhill.

The aim of the research project was to explore students' understandings of citizenship and how these were challenged through taking the module. Prior to the module students were invited to engage with the research project, although this was not a precondition for taking the module. Students were enthusiastic, and the research agenda was negotiated at a meeting prior to the commencement of the module. Students subsequently participated in focus groups, (transcribed and interpreted thematically) and provided feedback during the module by course evaluation forms. In 
addition, we as researchers kept a research diary, which included bibliographic research and notes on our emergent understandings grounded in our observations as the module developed. Research findings were communicated and discussed at the end of the module.

The research which we conducted into the process led us to concur with Gerry Stoker's argument that active citizenship is hard to do (Stoker 2006). Our interpretation of this is that doing citizenship can be conceptualised as a process of transformation from a model of citizenship defined as obedience and successful socialization into dominant norms, which we call 'Being Good', to 'Becoming Active' an action orientated model of critical thinking and reflection, autonomy, and social justice. This raised issues for both our students and ourselves as we engaged with the task of becoming 'good citizens' in the contexts of values and expectations on the one hand, and multiple layers of identifications within the stratified contexts of the local, national, global formations of states and markets on the other.

This led us to challenge Crick's citizenship agenda (QCA 1998) from the perspective of locality, arguing that situating citizens allows us to think sociologically about the task of citizenship as a problem of praxis found in the everyday life of the classrooms of the education system, and beyond. We found that the Crick agenda is underpinned by assumptions of homogeneity, which disembeds citizens from their locality and experiences of community lived in stratified social contexts characterised by diverse cultures. Thus, we conclude with a political demand for an understanding of situated citizenship to inform our education policy, pedagogy and practice. By this we mean a model of citizenship that is based on an assumption of both national and local heterogeneity and positive sensitivity to diversity.

\section{The contexts of citizenship education and debate}

Ever since the Crick Report (QCA 1998) recommended that citizenship education was an appropriate area of study with which schools should engage as a part of the core curriculum, the education system has been faced with the dual challenge of both grasping how an effective citizenship education could be defined, and finding ways of implementing it (Oulton, Day, Dillon and Grace 2004). Active citizenship was defined by the Crick Report around three elements appropriate to the task of learning about citizenship. First, citizenship education should foster social and moral responsibility, self confidence and responsible behaviour. Second, it should promote community involvement by encouraging students to learn about and get involved with their communities. Finally, it must inculcate political literacy in order that learners of 'citizenship' be effective in public life and understand how political decisions are made and how political institutions and processes operate. This we felt to be significant, and we chose 'Doing Citizenship' as the title for our module in order to foreground our agency-based approach. The English Citizenship Order (1999) introduced citizenship education as a part of the core curriculum based upon the findings of the Crick Report, and this has generated a new wave of activity and debate throughout the education system, including higher education (Lockyer, Crick and Annette 2004). The citizenship agenda can be located within a wider concern about political disenchantment and disengagement (Norris 1999, Giddens 1999, Dalton 2004) as well as more generalised anxieties around the stability and nature of British democracy and of British citizens (Osler and Starkey 2000).

The citizenship debate has become a field of contestation. Audrey Osler and Hugh Starkey (2000) are among those who argue that the prevalent models of citizenship in the discourses which inform policy carry implicit assumptions about nationhood and the character of British democracy. Further, such discourses locate the task of citizenship as achieving social peace, this being characterised as an unproblematised melting pot of difference. This approach overlooks the diversity of aspirations and practices, as well as the multiple identities and meanings of active citizenship. Such meanings are explored by Derek Heater in his survey of the multiple traditions of citizenship. 
Heater (2004:326) argues that effective models of citizenship must be sensitive to the multiple dimensions of citizenship in feeling and practice, which requires special attention in education in order to engender good citizenship. Heater proposes model of citizenship defined by the planes of Education (skills, attitude, knowledge); Elements (identity, virtue, legal/civil, political and social); and Functional Networks (world, continental, national, provincial). Heater thus places great significance on what he terms the 'geographical level', noting that '...each of these elements must be experienced in a geographical context....it is becoming increasingly evident that the function of the citizen can be discharged at multiple levels, from local government and functional interest groups through to the cosmopolis,' (2004: 326 ). This raises a challenge for traditional models of citizenship which set out models of allegiance to nationhood above all other entities. For Heater, the growth in demand for crude models of cosmopolitan citizenship are merely one step further, a conflation of duty upwards, causing attendant anxieties when loyalties are split between cosmopolitan, national and local levels. Heater argues against the monopoly of any level, suggesting instead that '... it is necessary to accept as perfectly feasible the notion that an individual can have multiple civic identities and feel multiple civic loyalties,' (2004: 327). However, this leads to a revising of the state, as one characterised by '...the diffusion of power and authority through many levels,' (2004: 327).

For Osler and Starkey (2000) among others, citizenship education must set a new agenda. They criticise the old citizenship agenda as representing a means of integration and control rather than participation and self determination. The 'new' citizenship agenda stresses active engagement and experiential learning. Osler and Starkey's curriculum would explicitly include qualities such as antiracism, community involvement and on in the management of the project. In Heater's more conservative model, citizenship education can act as a corrective to imbalances in the dominant model in practice in any state, for example, by producing citizens who can challenge authoritarianism.

Meanwhile back at the chalk face, evaluations of citizenship education have led to increased recognition of the barriers to the effective implementation of this curriculum policy once it lands in schools. Indeed, Ofsted inspections in 2003-4 found that while citizenship education provision was very good in one school in seven, and good in one in four, nonetheless in one in four it was deemed unsatisfactory (Ofsted 2005). The inspections identified a number of problems including lateness in introducing the curriculum; '...that key management decisions were based on misunderstandings and scepticism' (2005:3); approaches where citizenship education is an opportunity for enrichment for some, rather than an entitlement for all (2005:4); crowded curricula and lack of time; and the lack of written work and its relatively poor quality (2005:5). The inspections found uneven attention given to different areas of citizenship education, for example, human rights issues, law and government achieve relatively good coverage, while finance, diversity issues, and the role of the European Union 'are limited or absent' (2005:7). They also identified missed opportunities, for example to set up schemes to facilitate volunteering, even when willing partners are available (see CSV 2004).

Furthermore, it has been suggested that there is a fundamental tension about how to embed active citizenship, since schools still carry the task of fostering obedience and socialisation into dominant norms and values (Davis 2000) and they carry a control function at odds with participation, critical thinking and autonomy.

\section{Doing Citizenship with undergraduates}

We developed a second level, twenty credit module Doing Citizenship offered to students in 200506. The aims of this module were multiple. First, to explore different concepts of citizenship as Heater (2004) suggested. Second, to problematize citizenship in education as a field of study and as 
a site of citizenship dynamics. Third, we wanted students to think about citizenship education as a form of praxis. To this end, we sought to enable students to facilitate citizenship activities in order to enable them to move from commonsense and everyday understandings of citizenship to an informed and critical engagement. In doing this, we explored the citizenship of students and staff and considered the relationships between students, staff and the university. For example, the conduct of the course enabled students to share in the development of the curriculum by giving teaching time to issues that they raised each week and connecting these to the literature and research in the area.

The module ran over a twelve week semester using a structured lecture and seminar format for classroom-based sessions, and half or full day trips for the experiential learning sessions held offcampus. While we hesitate to suggest these as mutually exclusive categories, we think it helpful to position the class-based sessions as a different kind of learning experience to those that occurred) off campus in different learning environments. The curriculum began by problematising citizenship, examining it as a contested concept with its own intellectual history and conflicts. We considered citizenship in the context of social diversity, and stratified systems. We proceeded to frame citizenship in the UK as 'a problem of living' encountered in everyday life, including institutional systems such as education. From this point, the curriculum involved students' moving out of the classroom and into educational settings on three fieldtrips into various educational settings (a local Further Education college, a secondary school and a visit to Summerhill). These trips were interspersed with further taught sessions on the citizenship curriculum, citizenship and children's rights and radical approaches to schooling. A key component was sessions spent on evaluation and reflection.

Our underlying principle can be said to have been one of disruption where we attempt to deepen students' understanding by a process of defamiliarisation, rather than a more gradualist, accumulative principle. The aim of our disruptive approach was to allow space for Argyris and Schon's (1974) and Kolb and Fry's (1975) reflective practioners to emerge. Argyris and Schon's work on reflective learners starts from an underlying social analysis that society is in a constant state of flux or change. The ever-changing quality of social situations means that we constantly experience the novel and unique. Rather than relying on tried and tested formulas which tell us how to behave in particular situations, we become attuned to improvisation (albeit within the structural context). Argyris and Schon distinguish between the discourses that we use to explain what we are doing, and the actual thought processes on which we act. The difference between the two is the gap between the mental script or map which we have of a situation and how we think we should thus conduct ourselves, and the reality of our actual thought/feeling processes in which we may reflect upon that map, make adjustments as necessary, review our understanding of the situation and decide to make changes and act differently as a result. A gap therefore arises between the uncritically examined assumptions that we hold and the understandings which we develop in the real situations in everyday life.

Operationalising Argyris and Schon's (1974) ideas in the contexts of this module, we can see that students were pulled out of the usual institutional contexts and learning relationships of the university classroom. Students' understandings of citizenship were challenged because their preexisting models of behaviour and social theories about university learning, their and our roles within it, and how to do it, were no longer functional in the different settings in which they and we found ourselves. In the absence of prepared scripts and traditions that facilitate action, students were put into the classic situation of needing to 'think on their feet'. Back in the classroom for the debriefing sessions, students were asked to reflect upon the processes of adjustment that they had made. What strategies had they adopted to deal with the different situations that arose? How had their relationships with people formed and changed as a result? What had they found challenging, 
and how had they attempted to control the situation - and why? To what extent did they bring their own values, assumptions and norms to the situation and attempt to enforce them?

Asking questions of this kind facilitated students' thinking through their own theories of the world and how they activate them under particular circumstances. In their new roles, students were thrown into new relations of power. We encouraged them to reflect on the role of leadership by asking for example, what right did they have to enforce their own values? How did they facilitate participation of the groups with which they worked - and why did they believe this to be a good thing? And given that they were so committed to core concepts of 'good citizenship' at the start of the course, how could they explain why active citizenship is hard to do? This led to discussions about the citizenship of students and staff within the university, for example, about curriculum setting, roles in the classroom, and relations between staff, students, and institution. In addition, through posing questions of this kind, the module took the form of problem-based learning. In order to get by, students had to develop their capacity to reflect and act, gaining an insight into their problems as temporarily 'professional' citizens, developing judgement, in Schon's sense (Schon 1983) when scripts and traditions no longer function.

In terms of the effectiveness of experiential learning, we also comment here on possible connections with Kolb and Fry's model of experiential learning. The learning journal which students kept each week provided a means of operationalising the four-stage learning cycle: concrete experience, reflective observation, forming abstract concepts, experimentation and retesting. We found that the exercise fell down a little since students varied greatly in their diligence in making up their weekly journal. However, Kolb's theory was useful in the preparatory stages of the field trips, for example, in a series of acting and role-play exercises. For example, rehearsing group activities, developing coping strategies, and reflecting upon different tactics for working inclusively. In these exercises, students were invited to reflect upon their attitudes towards and definitions of, good and bad citizenship in both the university and other educational settings. Students worked in a variety of individual and group formations, for example, in pairs, listening to each other's experiences while the rest of the group observed their reactions.

We found that a major challenge was that of moving students from anecdotal to critical engagement, in other words, thinking sociologically. This was partly due to the timescales of the course, which unlike more classroom-based modules seemed very compressed. Students struggled to speak their experience, process it by thinking sociologically, and then sharpen that critique in the limited timeframes provided by the twelve week module. The team found that the learning journal which accounted for $80 \%$ of the assessment provided an additional space in which students could 'story' their experience of the module. However, both teaching staff expressed concerns to each other about the struggle to reach beyond reactions and 'stories' in a more anecdotal sense. Nevertheless, the learning journal provided a space within which narratives of self were connected to and contextualised within sociological and political concepts and theories.

The more general shift away from classroom-based learning opened up our awareness of risk and opportunity. Classrooms are 'easier' to control, they are relatively contained environments in which scripts of behaviour, norms and expectations will contain as much as any formally authoritative structure, real or imagined by its participants. Engaging with schools and colleges, making field trips, and deliberately placing students in leadership roles (in which the academic tutors did not lead or indeed intervene) all create different kinds of learning settings, and indeed different relationships between the learners. For example, students commented on the insights they had gained into the role of university lecturers. Being in the position of tutors also led students to re-appraise the identities of their peers, seeing each other in active and engaged leadership roles rather than as passive recipients of knowledge. 
At the end of the module, students were invited to participate in a focus group. The questions focused on what the students felt the outcomes to have been. What experiences did they wish to feed into the reflection process? We noted both in our focus group interview with the cohort of students, and in our own discussions, that as academic staff we were compelled to trust the students and trust to the unknown, taking greater risks as the course unfolded. Our relationship with the students in the course were different as a result of being outside of the confines of the University environment, in places and settings which were unfamiliar to all of us both staff and students alike. Roles and identities were displaced and reviewed and new relationships of trust established.

\section{Situating Citizenship}

We now turn to consider the learning experiences of the field trips, and how this leads us to identify and problematise 'The Good Citizen', and to take forward our demand to situate citizenship, if active citizenship is to be realised in practice.

Situating citizenship in the context of East London is to recognise the transformations of the area, characterised as a region where a restructuring of capital and services is underway. The 2012 Olympics, with its regional impact provides a vehicle for the expansion and acceleration of the regeneration throughout East London and the Thames Gateway by re-forging its connections to the global and restructuring the local. This has opened up a field of contestation, since it raises issues about the character of these connections and how they are made. The long reach of regeneration is leading to a re-organisation of communities and their networks, producing opportunities and stratification.

Social statistics from the 2001 Census for the London Borough of Tower Hamlets in which most of our field trips were conducted shows the social basis for some of these issues rather well:

* Canary Wharf produces 35\% of all GDP in financial services in Britain,

* $51 \%$ of the population describe themselves as White; 33\% Bangladeshi; 3\% Black African; 3\%

Black Caribbean

* $64 \%$ of school age children speak English as a second language

$* 49 \%$ of working age employed (England and Wales 60\%)

* 39\% 1-person households (England and Wales 30\%); this includes young professionals living in recently built flats at the aspirational end of the entry-level property ladder

* 38.6\% Christian; 36.4\% Muslim; 14.2\% No religion. The population of Muslims is the largest in the UK

* $57 \%$ of households without car or van (England and Wales $27 \%$ )

* 30\% of the population engage with Higher Education (England and Wales 19.8\%) this reflecting the diversity of the population which includes both middle class professionals and a young demographic profile for some of whom education is an aspiration; and the short term nature of mobility between kinds of activities within a mixed economy of education, training, paid and unpaid home based work. (Census 2001).

Thus we can see that the Borough is one of contrasts, raising issues for the successful conduct of citizenship within the locality. We now turn to explore how some of these 'social statistics' surfaced in our field trips.

\section{Pedagogy and Practice in East London}

Students taking this module spent a morning with a local East London Borough where they undertook a workshop which provided a briefing on the communities in the Borough and the issues and problems of youth engagement, participation and inclusion found there. Students then learned exercises from The Democracy Cookbook (2005) a resource for working with young people 
produced by the Electoral Commission, which they adapted ready to implement with students from a local further education college later that day.

On first arriving in the College, our students were involved with the Borough's campaign to increase the registration of young voters. Our students attempted to get the College students to register for the vote. The context was the forthcoming local elections, in which George Galloway's Respect Party stood against Labour and the extreme right British National Party campaigned heavily, hoping to build on successes elsewhere in East London. Our students had some success in getting young people to register to vote. They reported two common reasons. First, they could appeal to the sense of civic duty of the further education students as British citizens in a democracy. Second, they found the young people committed to an agenda of combating the threat of racist politics, and discussed the importance of supporting the Labour or Respect parties in order to prevent the British National Party from obtaining a hold in Tower Hamlets.

However, our students also experienced difficulties in getting young people to register to vote. Our students suggested that one reason for this was the citizenship status of some further education students - some were not British citizens and could not vote in local elections; in addition, while most of the further education college community were of an age to vote, the mixed economy of educational provision meant that our students did encounter a small knot of young people who were not old enough to register to vote. There were others for whom disengagement was a key factor. Some held the view that there was no-one to vote for, this tended to refer specifically to the Labour government and policy in Iraq. This was considered highly problematic by many of the College students as well as our own, since their home contexts include both engagement with local Labour Party politics alongside Muslim associations who had a range of responses to the events of September $11^{\text {th }} 2001$ and the July Bombings in London 2005.

Disengagement is related to a more generalised perception and experiences of marginalisation and powerlessness, as conceptualised by our students. One student understood this problem as:

'...What these kids think is 'my vote won't change anything' and they just give up' DCTCS1

This was also interesting, since equally we can regard the withholding of civic duty as a resistive and critical measure, not necessarily a measure of apathy and silence.

Following the voting exercise, students rose to the challenges of leading groups of further education students through exercises which asked them to a) Build your own politician: what makes a good politician? B) The $£ 250 \mathrm{k}$ game - groups competed to spend a sum of money on one project of choice which would '... significantly change my neighbourhood for the better'. In these exercises, students battled with silence, apathy, conflict, competing ideas, enthusiasm and so on, as they tried to achieve 'democratic' participation. Prior to this experience, our students had been strident advocates of liberal democratic values including using the vote as a teaching tactic to resolve disagreements within the group, and going around the group to ensure that each person spoke and that each suggestion was recorded and seriously considered by the group. However, the students found these easily assumed ideal models of teaching democratically challenged. For example, in the proposals for investment in the local neighbourhood, two proposals came equal first as a result of voting by the college students. These were a communal area for young people including a football pitch, and a nail bar for young mothers, thought to be especially needed if they were lone parents.

Our students were dismayed by the gendered nature of the voting, (since there was a clear gender divide in the voting for the two most favoured proposals). Our students grappled with the problem as they saw it of a hierarchy of proposals for example, of their quality; what should they have done if proposals put forward were 'too stupid' or 'impractical?!' Our students were also critical of crude 
interest group behaviour, (voting for a friend's proposal; voting with an ulterior motive etc.), rather than voting for the issues. The students when confronted with these problems in the classroom were involved in a struggle which they understood in terms of participation versus control. When faced with their own and others' lack of strategies to produce effective participation, they lurched towards control. Recognising this tendency, students made ever greater efforts to rise to the challenge as one student explained:

'...They were confrontational but we did a deal with them right, and we said 'Look, let's make these rules' and they said 'Okay.' (DCTCS2)

The fieldwork experiences in the school and the college in the Borough raised issues for our students, including thought-provoking challenges around the layers of identification and diversity found within different populations and the problem that participation and democracy are hard to achieve. While in theory all may sign up to narrow but laudable models of national citizenship and civic decision making, students were struck by how ill suited a one size-fits-all approach was in both theory and practice.

\section{Schools in the City}

The second field trip to a school in East London was conducted in two parts, with work undertaken by students and pupils in between. Working alongside the class teacher and an actor, students explored stereotypes with pupils, including stereotypes of Londoners as well as those of people from different parts of the world. Students then facilitated small group discussions helping pupils to identify areas of interest which they could then research. Students helped pupils to establish a plan of work to be conducted before the second, concluding visit in which findings were presented and discussed. This trip brought the issue of 'participation versus control' centre stage, since the group encountered a series of difficulties. According to one student:

'It's the attention span, it's like 10-15 minutes and they keep interrupting and I think 'how do they organise things like trips, how do the staff cope with all the kids bickering. You start, and then it's like 'Shut up! Shut UP!'(DCTCS3)

However, if national citizenship is precarious, can local identities stand in their place? In one exercise, the school class focused on what it meant to be a Londoner. The school pupils thought that 'being a Londoner' described everyone quite well, until picking through what people who live in different parts of London might be like, and more to the point, how for example, people from other parts of London might regard people from the East End. Reactions to this surprised our students, particularly the negative images and low self esteem held by pupils who clearly defined themselves as from the East End. One student reflected:

'...That exercise comparing Finchley with Tower Hamlets viz people's stereotypes about each other, I thought 'Will they know what people of Finchley think of them?' I was surprised at them.... and that they saw themselves so negatively.' (DCTCS4)

Our students were dismayed by the lack of engagement which pupils showed, and made a gloomy prognosis of the future of active citizenship for these East End children:

'Most kids in Tower Hamlets don't think that [it is effective to engage], that's a lost generation if we are not careful...' (DCTCS5)

The experiences of engaging with young people in a school and a college in Tower Hamlets did impact our students. The impact can be viewed as a process of defamiliarisation, where new information is brought in with the effect of challenging existing identity and roles. In the following 
student's case, it is notable that he had a history of engagement with local politics and had made important contributions working with young people from his community. His journey back into the Borough through the module caused him to question his high status and assured sense of self:

'It's made me think about what I do in my community: it's made me realise what kind of citizen I am... (DCTCS6)

By this the student explained that he meant that he questioned how his status and identity would change if he were to leave the Borough and live away from what he considered as his community. These kinds of explorations of identity and belonging brought out for us the heterogeneity of citizenship and the extent to which citizenship as a local engagement was more important than any national, regional, or global narrative.

\section{The field trip to Summerhill}

The field trip to Summerhill allowed students the opportunity to meet Summerhill pupils who showed them around and allowed them to share (but not to participate in ${ }^{1}$ ) a School Meeting. This was followed by a group interview with Zöe Neill Readhead (daughter of the founder who now runs the school) two former pupils, and an existing pupil. The trip was preceded by a briefing and discussion from a former member of staff who presented and discussed the school's slogan the 'oldest children's democracy.' Summerhill School in Suffolk was for all of us an utterly defamililarising experience that challenged us on many levels.

A.S.Neill founded the school in 1921, and was committed to the idea that education was about the development of the critical faculties of children rather than the satisfaction of parental expectations, or the reproduction of dominant norms:

'Obviously, a school which makes active children sit at desks studying mostly useless subjects is a bad school. It is a good school only for those who believe in such a school, for those uncreative citizens who want docile, uncreative children who will fit into a civilisation whose standard of success is money'. (Neill, reprinted in Vaughan 2006:6)

The School Meeting is one of the major vehicles by which the citizenship community practices self governance. Held three times a week any adult or child of any age can chair the meeting and raise matters for discussion. When decisions are made, it is by show of hands in which the vote of the Head is equal to that of the youngest child. Adults and children are defined as equal citizens and collectively establish the rules by which the school community then abides on a daily basis. During our visit, the twelve year old Chair both fined another child ten pence for talking, and demanded that two older teenage boys were split up and that one of them would go to sit quietly at her feet which he did. It is claimed by the Summerhill community that it is in this way that collective discipline is maintained.

A second major mechanism of self governance is the self determination of learning. Children are not compelled to attend lessons, rather teachers put on classes at request. This is a bone of contention with regulatory authorities including Ofsted inspectors (who argued to close the School in 2000) since children rarely meet the benchmarks set for each subject level of attainment at the 'right' age. In this sense, we argue that the school is a strong embodiment of self-directed learning and attempts to implement the UN Convention on the Rights of the Child. Yet the UN Convention itself stops short at citizenship, children do not have equal rights of participation in community

\footnotetext{
${ }^{1}$ The rules of the Summerhill community provide for visitors to attend but not to participate unless specifically invited to do so, this being decided by vote by the School Meeting prior to visitors being allowed entry. Thus, we waited outside of the School building while the Meeting was opened, until a pupil came to let us know the outcome and show us the way in.
} 
affairs and are formally excluded from most politics. There is then a contradiction for adult citizens (like our students) working with children who are at best enfranchised in limited, local, specific ways - when adults allow it, and perhaps because they feel sufficiently in control of its governing frameworks. A real concern then, for our students, was what would happen to these active and critical citizens which they encountered at Summerhill. What sort of future did they have and what would happen to them when they had to enter 'the real world'? Students expressed concern about enjoying active citizenship if it were only to be a temporary state of affairs.

Our students had a range of very strong reactions to their time at Summerhill. There were concerns about children being away from their family, about dirt and scruffy hair, and about the apparently low status and poor living conditions of teachers (decrepit caravans parked in the school grounds and a disclosure of 'institutionalisation - the only people we ever see are each other.'). One of our students who describes herself as a working class mother was specifically unhappy with the living conditions and lack of adult authority. After being shown around the school, she initially chose to sit by herself in the grounds, expressing a wish to go home and be left alone. Later she rejoined the group. Another student expressed her concerns in terms of 'race', seeing a young Black child as alone in a White school, while other students saw isolation in Summerhill as an institution with its leafy grounds in the green villages of affluent Suffolk. There was some merriment and conjecture about how the children 'got out' at night - how did they get to and from the amenities offered by the local town? For some of our students, specifically those who were born and raised in London, these leafy (and unlit) lanes provided new dangers, of being followed and attacked perhaps, or stranded by a rural bus service, certainly, of being unable to grow up in an urban neighbourhood in which you were in some senses known and safe. 'It's like they're shipwrecked here,' (DCTCS8) said one of our students. Our students felt in general that the Summerhill community were active citizens, and yet their geographical isolation was a metaphor for their social dislocation. There was a sense that these 'good' citizens were made idiosyncratic by the 'bad' citizenship which awaited them in the 'real' world.

\section{Situating Citizenship: The Good Citizen reconsidered}

There appear to be startling differences between the models of citizenship on offer in the schools and the college which we visited. These differences raised an important question for our students as experiential learners. As Kolb and Schön suggest, the various direct experiences of citizenship in education disrupted our students' preconceptions and established learning, often in ways that they neither expected nor desired. In the classroom, our students demonstrated an intellectual commitment to radical models of citizenship in education. Their experiences in the college and the school however, brought cynicism and even brought some of our students up short as they reflected on their preconceptions of the behaviour and values of some of the potential citizens which they had encountered. They all concurred that the model of citizenship in education that they found at Summerhill was one of active and full participation, this was, they felt, genuinely a children's democracy. Yet they were disturbed by what they saw, and some demonstrated a very real conflict wherein support for children's rights and democratic engagement was brought into conflict with some cherished ideals about community-as-neighbourhood and locality, familial relations and traditional authority structures.

The project revealed the extent to which citizenship is a locally experienced problem of praxis encountered in different kinds of educational citizenship settings in different ways. Our undergraduate students were confronted with alternative notions of citizenship in theory and practice, and were asked to make responses which required active engagement and participation on their part. We found that we can concur with Stoker's view that citizenship is hard to do, and note that the Crick curricula may oversimplify the task of doing citizenship in educational settings, by assuming a disembedded notion which speaks of a national and unified paradigm and which overlooks the problem of praxis encountered in doing citizenship on the ground. The negotiation 
and contestation of citizenship can be realised in a range of ways. Students and ourselves as staff members were interested to compare and contrast the thinking and practice found in the schools, the further education college, and Summerhill. The context of university education raises critical issues about our own citizenship and the specific kinds of understandings achieved and interventions which become possible.

For our students, the dominant learning experience for this module was storied as one of discovery, this is a typical example:

'I was a bit sceptical, I wasn't sure I was going to enjoy this module. I thought 'Oh my gosh! I've got to go out into schools - I was really worried. I've really changed...it's all so interesting. We were all looking out for each other's interests and that's all part of citizenship. We're not just sitting in the classroom writing, we're going out there, we're getting involved'. (DCTCS7)

This journey of discovery was of the heterogeneous and contested nature of citizenship. We conclude that the module provided a mechanism by which the situated nature of citizenship was made explicit and its praxis was exemplified.

\section{References}

Argyris, M. and Schön, D. (1974) Theory in Practice. Increasing professional effectiveness, San Francisco: Jossey-Bass.

Census (2001) Census On-line. London: The Office of National Statistics. http://www.statistics.gov.uk/census2001/census2001. (accessed April 2006)

Community Service Volunteers (CSV) (2004) Citizenship in the curriculum two years on, London: Community Service Volunteers.

Dalton, R. J. (2004) Democratic Challenges, Democratic Choices: The Erosion of Political Support in Advanced Industrial Democracies, Oxford: Oxford University Press.

Davies, I. (2000) Implementing Citizenship Education: Can it be done? The School Field, XI (3/4): 91-110

The Electoral Commission (2005) The Democracy Cookbook, London: The Electoral Commission. Giddens, A. (1999) 'Democracy', Lecture 5 in BBC Reith Lectures series entitled Runaway World, <http://news.bbc.co.uk/hi/english/static/events/reith_99/> (accessed 25 April 2008).

Gifford, C., Burnett, J., Watt, P., Cudworth, E., Coster, S., Clark, W. (2006) Working with Schools: Active Citizenship for Undergraduate Students, Higher Education Academy Subject Centre for Sociology, Anthropology and Politics (C-SAP), project reference: 23/S/05.

Heater, D. (2004) Citizenship: the civic ideal in world history, politics and education, Manchester: Manchester University Press.

Kolb. D. A. and Fry, R. (1975) 'Toward an applied theory of experiential learning', in C. Cooper (ed.) Theories of Group Process, London: John Wiley.

Lockyer, A., Crick, B. \& Annette, J. (2004) Education for Democratic Citizenship: Issues of Theories and Practice, Aldershot: Ashgate.

Norris, P. (1999) Critical Citizens: Global support for Democratic Government, Oxford: Oxford University Press.

Office for Standards in Education (Ofsted) (2005) Citizenship in Secondary Schools: Evidence from Ofsted Inspections (2003/04), London: Ofsted, HMI 2335.

Osler, A. and Starkey, H. (2000) 'Citizenship, human rights and cultural diversity', in Osler, A. (ed.) Citizenship and Democracy in Schools: Diversity, Identity, Equality, Stoke on Trent:

Trentham Books, pp 3-18.

Oulton, C., Day, V., Dillon, J. and Grace, M. (2004) 'Controversial issues - teachers' attitudes and practices in the context of citizenship education', Oxford Review of Education, 30(4): 489-507. 
Qualifications and Curriculum Authority (QCA) (1998) Education for Citizenship and the Teaching of Democracy in Schools Report of the Advisory Group on Citizenship, (The Crick Report), London: Qualifications and Curriculum Authority.

Schon, D. (1983) The Reflective Practitioner. How professionals think in action, London: Temple Smith.

Stoker, G. (2006) Why Politics Matters: Making Democracy Work, London: Palgrave Macmillan. Vaughan, M. (ed.) (2006) Summerhill and A.S. Neill, Maidenhead: Open University Press. 